\title{
ENVISIONING A PARTICIPATORY DEMOCRACY: AN INTERVIEW WITH JOHN SHOTTER ${ }^{1}$
}

\author{
Carla Guanaes-Lorenzi² \\ Pedro Pablo Sampaio Martins \\ Clarissa Mendonça Corradi-Webster \\ Kátia de Souza Amorim \\ Universidade de São Paulo, Ribeirão Preto-SP, Brasil \\ Emerson Fernando Rasera \\ Universidade Federal de Uberlândia, Uberlândia-MG, Brasil \\ Murilo dos Santos Moscheta \\ Universidade Estadual de Maringá, Maringá-PR, Brasil
}

\section{POR UMA DEMOCRACIA PARTICIPATIVA: UMA ENTREVISTA COM JOHN SHOTTER}

\section{POR UNA DEMOCRACIA PARTICIPATIVA: UNA ENTREVISTA CON JOHN SHOTTER}

John Shotter is an Emeritus Professor of Communication at the Department of Communication, University of New Hampshire (United States of America). He is also a Research Associate at the Centre for Philosophy of Natural \& Social Science (CPNSS), London School of Economics, in London (United Kingdom). He is one of the founders of the social constructionist movement in the human sciences, and especially in psychology. In dialogue with many textual friends - such as Wittgenstein, Bakhtin, Vico, Mearleu-Ponty - John Shotter's work has been of central importance in promoting a critical view of modern human and behavioral sciences, their limits and their consequences. As he defined on his website (see http://pubpages.unh.edu/ jds/), his long term interest has been in "the social conditions conducive to people having a voice in the development of participatory democracies and civil societies". More recently, he has pointed to a need to push forward the contributions of the social constructionist movement itself, for he considers that many versions of it are "still infected with the Cartesian view - that mind and body, subjectivity and objectivity, are completely separated - a view that in fact they aim to overcome". This leads us to adopt in our reflections on our difficulties in the word, what he calls about-ness thinking and talking rather than with-ness thinking and talking; to conducting our discussions in terms of representationalreferential understandings rather relationallyresponsive ones.

\footnotetext{
1 Acknowledgments: We thank Martin Webster for listening to this interview and reviewing its transcription.

2 Endereço para correspondência: Faculdade de Filosofia, Ciências e Letras de Ribeirão Preto - USP, Departamento de Psicologia, Av. Bandeirantes, 3900 - CEP 14.090-901 - Ribeirão Preto-SP. E-mail: carlaguanaes@gmail.com
} 
In his recent dialogical writings, John Shotter has emphasized participatory modes of life and inquiry, privileging the understanding of unique moments and circumstances in which people make sense of themselves and of the world in which they live. A world of living, embodied beings, spontaneously responsive to each other. People in their everyday relations to the others and othernesses around us, do not need to analyse and explain their actions scientifically to be able through everyday reflection and inquiry to improve them. Practitioners are their own best experts on their own practices - if questioned in ways which reveal the relations of their practices to the surroundings in which they are performed. Since then, John Shotter has been pointing to the importance of working with practices rather than theories, and has been developing a very productive dialogue with practitioners in the most different fields, as family therapy, health care, and organizations.

Last year, we had the honor of receiving the visit of Professor John Shotter at the Graduate Program of Psychology at the University of São Paulo, in Ribeirão Preto. During one week, professor John Shotter gave lectures and coordinated meetings with different research groups, talking with professors and undergraduate and graduate students of that institution, thus sharing his vast knowledge on psychology, science and life with an attentive and curious audience. This interview was developed on the last day of professor John Shotter in Ribeirão Preto, in October $10^{\text {th }}, 2012$. It certainly can be described as an arresting moment, in which Professor John Shotter shared his ideas, disquiets and dreams.

In this interview, professor John Shotter 'dialogues' with many authors. He presents his aim of contributing to the construction of a participatory democracy, and reflects on how his work helps to promote a psychology more sensitive to a view of human being in relation to others and to their surroundings. He shows himself very critical to the unceasing search for names, labels, and models of traditional psychology, reminding us that human beings are not machines, which can be decrypted and fixed. As human beings, we are unique, complex and remarkable. Along this interview, stories, metaphors, meanings and sounds are intertwined. Two different, but complementary things emerge from this dialogue: On one side, a strong sense of critique to the traditional psychology field and, on the other, a lot of hope on our possibilities of constructing a better world.

To publish this interview is a way to honor professor John Shotter for his brilliance as an academic and as a human being and, once more, to thank him for his enormous generosity, availability and goodness. It's also a way to keep this conversation going, building other dialogical possibilities.

\section{INTERVIEW}

Carla: We requested this interview with you to talk a little bit about your work. But it is a challenge, because you talk about so many important ideas... So, we decided to talk about a very broad theme: Your relationship with psychology as an academic discipline. To start, in the academic life, we learn many different theories, many different ways of thinking about psychology. We would like to know what is the object of psychological investigation, in your opinion? Or what should it be?

John: Well, I think it's on my website where I say that my purpose is to try to understand what a participatory democracy would be like rather than a representational democracy. What's involved in people coming to an understanding of the conditions of their own lives. Thus strangely, for me, I'm not very interested in people's ideas, in what they think.

I stole a very nice saying from somebody who was a follower of James J. Gibson (1979) and his ecological psychology; you might have heard me saying it already: "Don't ask what goes on inside people's heads but ask what their heads go on inside of".

I wrote a book in 1984 (Shotter, 1984), where I called what I was doing then "social ecology", and to an extent I have returned to that.

An Austrian ecologist, Jakob von Uexküll (1957), was a very nice author who was concerned in bringing to visibility the inner life of different 
animals. In his articles, he writes about the inner life of a housefly, the inner life of a sheep tick, the inner life of a child compared with an adult, and so on. And, as he said, a simple animal lives in a simple world, and a complicated animal in a complicated world. In that sense, we can extend the idea of an ecological niche to our professional lives. He talks about your Umwelt [German for environment] in the surrounding world; and you can come to an understanding of the organism's inner life in terms of what they pick out to respond to psychologists picking out different things to attend to than linguists, for example. I followed that kind of approach really for quite a long time, actually.

I think on my first day here I said l'd been very lucky with some of the people I have met. I did my undergraduate degree in Psychology in the evenings at Birkbeck College, London, while I worked as an electronics lab-technician in the Speech Laboratory of the Phonetics Department, University College, London. There I met Basil Bernstein (1971). He was concerned at the time with the sort of world of working class children lived in compared with the world of middle class children, and he used the idea of code - not like a Morse code, but a DNA code - that determines the growth of a child, into a person of this or that kind.

In business studies these days, a lot of people say that a company has a certain DNA to it. And when one company buys another one, the company that they have just bought, the people bring the DNA of that company into the parent company and it makes for difficulties. Somehow, Basil Berstein was saying that there was a DNA, a social DNA at work producing a certain way of being a working class person compared with being a middle class person. So my approach has always been looking at the organism in relation to its larger surroundings.

Katia: As you said, you have sustained your work in a social ecological approach to the understanding of human kind and its relationship to the world. You can also be considered as one of the most important authors in the diffusion of the social constructionist movement in human sciences. So, how do you consider this view in relation to the mainstream or traditional psychological field?

John: A large part of psychology seems to me obsessed with what I would still call a Cartesian vision that there's something 'in here' [pointing to his head] which corresponds to pictures of what is out there; and this is very apparent for me as still the case in current neuroscience and brain scans and things like that. Whereas, I'm very sympathetic to James J Gibson's (1979) ecological approach where he talks about our surrounding circumstances as making "affordances" available to us. Although, like Maturana, who doesn't talk of language, but of languaging. I would rather talk of "affordings", rather than affordances. I wish, in fact, we have a verb-language rather than a noun-language.

So my relations to traditional psychology? A simple answer is: Are not good ones. A very good friend of mine in England, he is a very well known social psychologist, Michael Billig, wrote a very nice book on Freudian repression, in which he presents a dialogical account of Freudian repression (Billig, 1999). You could find a paper of his in which he discusses the process of "nominalization", that is, the obsession of psychology with naming everything (Billig, 2008). He talks about nominalization and passivization as erasing agency and stripping everything away from its context. But what Michael Billig is saying is to repeat what Marx said a hundred 
years earlier. In the 'German Ideology', there are three tricks for the construction of ruling illusions: First you collect data, while forgetting who said it and the context in which they said it; just record what was said. The second step is to find a pattern in what was said. And the final step is to invent an agency that you take to be responsible for that pattern.

In outlining these 'tricks', he was being critical of Hegel's claim that we are victims of "the Spirit of History". The process is a common one. Later people said we are victims of technology, and there's nothing we can do about it. Now we are all victims of a financial crisis, and it seems as if there is again little we can do about it. But Karl Marx also said: "Human beings do make history, but history isn't made behind our backs. We make it."

This is why one of the first things that really captured my interest, was what I called "joint action". It can be illustrated by the Ouija board example, in which everyone in a group of 5 or 6 puts their fingers on a wine glass ${ }^{3}$. It starts to move around... and if you've ever done it, you feel like you have to make quite an effort to keep your finger on the rim... you experience it as if the wine glass has a life on its own. But as soon as everybody takes their fingers off... Nothing!

So l've been interested in join action, in those kinds of activities that only happen with people meeting each other. But it's impossible to trace back the outcome of what happens in these meetings to any particular individuals. It is these kinds of influences where an outcome that we are not in control of in any self-aware way, but nonetheless we are the ones producing these kinds of outcomes, that have always interested me.

3 In Brazil, this practice is usually known as the "glass play", a game that is related to the presence of spirits which are trying to leave their message.
And, perhaps, the second part of the answer is: In many ways I don't care what the area is in which I work. Joint action - and its near cousin, the dialogical - function everywhere. It so happens that I work quite a lot in healthcare and psychotherapy.

But back in 1995, I think, I was kind of 'head hunted' to work with Björn Gustavsen with the Swedish agency "learning regions project" (Gustavsen, Nyhan, \& Ennals, 2007). This took me into industries, local government, and other 'worklife' projects. Then, by being friends with other people, I was drawn into working in organizations. But these kinds of processes are at work everywhere... [pause]. I don't know if it's noticeable but, a little bit like Tom Andersen, halfway through my career I stopped worrying about theories and began to start articles always with a fairly detailed concrete example. So you start with particular phenomena rather than good ideas.

Clarissa: John, in some way I think you had already answered my question. When you were answering the last question you referred to the notion of joint action, which is, on my point of view, one of your most important contributions to the understanding of how people make sense of their environments. When you review the history of your work, all your articles and writings, what do you consider that your main contribution to the psychological field is?

John: I have no idea! I really haven't... I would say, in one way, l've led an extremely privileged life. When I finally left a Psychology Department, I used to think, half my energy was spent getting the time to use the other half of my energy in what I was interested in. And when I moved in to a Communication Department [University of New Hamsphire, USA], I began to feel I was using $100 \%$ of my energy in what I was interested in. And I do have to say I have a degree of contempt for academic psychology. 
There ought to have been lessons learned by now.

When I first went to America, I went to an APA (American Psychological Association) meeting in New York. There were 14000 delegates there. I remember walking along in this corridor where the doors of various symposia were open and almost every door I passed I heard somebody say "Now, in my model...". I thought, "Fourteen thousand models... Is there a possibility of anyone of them being the right one"? And that was in... What was that? That was in 1990, I think. So you go for, I don't know for how many APA meetings and 14000 models of each APA meeting. This production of models after models after models... Has psychology actually contributed to anything that really matters? In fact, I think it's almost the opposite. This psychologization is the kind of colonization of the everyday life world, which Habermas talked about. This continued discovery of new deficits. Or continually telling us it's all a matter of biology, it's all genetics, now it's all neuropsychology, it's all our brains. Our brains tell us to do this, our brains tell us to do that... [pause]... I'm sorry, but I just feel that I have to oppose that.

I mentioned Gilbert Ryle and his book in 1949 "The concept of Mind" (Ryle, 1949). The theme of that book is what he called the "ghost in the machine." The mind is the "ghost in the machine." There is a line in there that says "People are people, a tautology worth remembering". People aren't machines. People aren't organisms. People are people. [long pause].

Murilo: John, by hearing your words, I have the impression that you've been going through different areas, much beyond the field of psychology. As you go through all these experiences, do you have a sense of what is it that you've been thinking, saying and offering that has been most inspiring for the others who are with you?
John: Michael Billig is a very close friend and he does actually say to me: "John, no matter how awful you think psychology is, you're still a psychologist." [laughter]. And I think he is right. Wittgenstein says "Nothing is so difficult as not deceiving oneself". It is a matter of trying to think through the way in which all of the social sciences work to try and to get a sense of our everyday reality.

Every time somebody invents a model or a concept or a theory or whatever, a new metaphor emerges. I try to come to an understanding of how useful that is, but also to an understanding on the way in which it limits. Psychiatry is limiting, for instance, and the way so many products of psychology, they seem, on the one hand, when they first come on the scene, to open some new horizons. But then they kind of become dominant and doctrinaire and start closing things down again.

What I was trying to say about John Macmurray $(1957,1961)$ and the idea that human beings babies adapt, when they are born, what it is the Darwinian adaptation, and adapt to being nonadapted. Unlike other animals, there's no obvious ecological niche for human beings. And I wrote a little about that, in 1975 (Shotter, 1975).

Besides Giambattista Vico (16681744), there is Pico della Mirandola's (1463-1494) discourse "Oration on the Dignity of Man" (1486). It's a marvelous little piece, because he's saying that by the time God created human beings, God had run out of patterns, models for them. Thus God said to human beings: "it's your task to make yourselves, and you have the choice of ascending to the angels or descending to the beasts, that is up to you." You could say he was the first social constructionist.

A very early article I wrote (Shotter, 1974) was simply called "What is it to be human?". The main thrust of that article is, to be a human being is to face up the having the responsibility of 
being someone, the responsibility for your own actions. It's up to you the kind of person you become. [pause]

So that was one of the things that got me first in trouble. Because I said "psychology is not a natural science of behavior, it is a moral science of action". And that actually got me hit physically hit - a couple of times in talks on that, because the people in the audience took me, literally, as accusing them of being immoral. And they were right. That was when almost all social psychology experiments involved deception. It was before Psychology Departments had ethical committees that you had to submit your experimental procedures to [pause]. But, I have to say, I do not know what my own relation to mainstream psychology is now. All I know is that I get invited to work a little bit here, a little bit there and a little bit somewhere else and so on and that's what I do. [pause]

Pedro: John, as I hear you speaking, I sense you have a very strong commitment with your ideas and ideals. During this wonderful week with you, we heard you quoting Tom Andersen many times, in his saying "I have a restlessness in my body and it won't leave me alone"...

John [at the same time]: Yes, yes, yes.

Pedro: And, we were wondering what's your restlessness at the moment?

John: Oh, my God! [laughter]. So many... But, you know, this is nothing new, and it's not just me. A book that l've got in my bag and promised myself I would read on the airplane. Have you heard of Amartya Sen? Amartya Sen is Indian. He was the husband of Martha Nussbaum. And there's a very famous earlier writer, John Rawls (1971), who wrote a book named "The Theory of Justice". Amartya Sen's (2009) book is called "The Idea of Justice". But Amartya Sen starts off with a criticism of Rawls's work by saying that John Rawls was trying to understand ideally what the idea of justice is, what perfect justice would be like. Amartya Sen is critical of this, he says: An alternative approach is to not to begin by asking what a perfectly just society would look like, but asking how might we remove experienced injustices, about which there is a better possibility of agreement. And he quotes the character Pip, in Charles Dicken's Great Expectations, who says: "In the little world in which children have their existence, there is nothing so finely perceived, and finely felt, as injustice." Nobody knows what perfect justice would be like, everybody has an argument, an opinion; we should start from lived experiences rather than what we wish to have in an utopian future. We can be pretty good - not perfect - but pretty good at identifying felt expressions of injustice; so we can set out to eliminate what occasions such unjust activities.

So when I quote Tom Andersen about his restlessness... We are reminded about the importance of not repeating something, just because it's the 'thing to do', but of working away from your disquiets, rather than towards your wish-for perfections. And everyone says it's no big deal, but we always feel not quite at home wherever we are. But, just with my partner Cherrie's experiences in the National Health Service in England 4 - I just begin to... I had never felt England to be such a corrupt country as I have done in the last two or three or four years. [pause] And so that's where I go [pause]. As soon as you get treatments which are being done according to recipes and tick boxes and protocols, and you get alienated doctors, alienated nurses, just acting mechanically, caring for

4 In one of his lectures at Ribeirão Preto, John Shotter referred to an example of a therapeutic relationship that Cherrie, a family therapist in the National Health Service in England, constructed with a young man held in a secure unit for young offenders, a relationship which offered possibilities not offered by any of his psychiatric treatments. 
people just disappears. [pause] Again, I used to say in the 1960's, I was very angry and then I calmed down and I now I find I'm getting very angry again. So, those disquiets... that's the general name I give to them. . . they're important.

And when it comes to business consulting, they've turned out to be tremendously useful. You have some business executives, and they talk all about their new strategic plan and they rattle on for between thirty or forty or fifty minutes about their brilliant ideas - and that's when they're up in their heads - then as soon as they say "but," and then they begin to talk about these difficulties with these people in the IT Department [Information Techonology Department], or those difficulties with these nerdy people in the research and development department, and so on. When they talk about their disquiets, then they are in touch with the real situations in the company. Their strategic planning is up in the air, it's utopian, it's not in touch with the real conditions of the company or the real time [long pause].

Emerson: John, when you talk about disquiets, you know, you have yours and I have mine! At the beginning of this interview, it was very interesting for me that you were talking about participatory democracy. And then you told us about social ecology, about paying attention to how we relate to our surroundings, and about the situation of England nowadays. When you think about psychologists and researchers, what's our role in society? What can we do to change it? What kind of knowledge do we need to produce in order to have a change in the situation in which we live? What do you think about it?

John: This is, I think, something I did share with Tom Andersen. It seems to me there is so much unused capacity and potential and energy out there. To an extent, you could almost say that it's very easy for psychologists to have contempt for the ordinary and the everyday. And I think in the Western world, in the last twenty or thirty years or so, we've had governments who've had contempt for ordinary people in their operations.

I'm sorry to say, I think, it may not be Obama himself, but the others Obama has collected around him... There's a book written about the Kennedy era "The Best and Brightest" (Halberstam, 1969), and Cameron is collecting around him "the best and the brightest".

I got myself, when I first went to Holland, I got a little bit of a reputation for myself for going round the corridors, stopping and saying "Oh my God! Not another good idea!" There, they had a new interdisciplinary program for new professors. It was a study guide of 800 pages, 800 models. The other British professor appointed along with me, called it "the McDonaldisation of Higher Education", I could call it a "Legoland degree of Plug Together Module McNuggets". The students were meant to have the choice of building the degree structure of their own out of these module McNuggets. But no sooner had the academics got it working, the administration came with yet another good idea that disturbed it.

Administrators in organizations don't understand that human relations are involved; that it's quite difficult to establish stabilities. So, I feel l've always been trying to understand at a practical level how these kind of participatory, collaborative programs can be established and brought to work.

And I suppose you know, I spent some time with Sallyann Roth in the Public Conversations Project (PCP) [see http://www.publicconversations.org/]. When Clinton was first elected, there was a Secretary of State, his name was Sheldon Hackney (chairman of the National Endowment for the Humanities (NEH) from 1993 to 1997) 
- and his mission was to establish various National Conversation programs. As was said about the Swedish Learning Regions Project, for regional development dialogues, when it got going, because no one could predict the outcomes, it was rather laughed at... Cameron has bleated on about what he called "The Big Society", but he never even took a first step in getting some of these kinds of things going. Tony Blair talked about "The third way", but in the end it was just rhetoric. When he first came to power, he had a mentor who was a monk, who had been a student of the John Macmurray I mentioned earlier, with his focus on persons in relation. And I was quite excited at first with Tony Blair, because I thought that all of the dialogical ideas that Colwyn Trevarthan and I were interested were in line with Tony Blair's project of establishing what he called "The Third Way" - bringing all voices together in a dialogic unity, I thought. But it was talk, rhetoric, impression management, not an attempt to create new practices, new social institutions.

So this participatory idea, there's been little spurts, little glimmers, here and there, which have then faded away again. I'm not the only one who's thought of all these, as far as I can see. But it is difficult for people to trust in the process, that it will be creative of new, unpredictable, possibilities. But I still dream. [pause]

\section{Emerson: So do I.}

John: And, so you said, "what can we, psychologists, do?" Well, all I can do here is to say, what Marcelo Pakman ${ }^{5}$ said: "Who is that we?" What makes a group of separate people into "a we"? Margaret Thatcher had a marvelous phrase and someone wrote a book

5 Before coming to Ribeirão Preto, John Shotter participated in an event in São Paulo, called "Constructioning", with Marcelo Pakman and Jim Willson. In that situation, Marcelo Pakman made that reflection. with this title: Somebody was proposed for her government and she said, "Is he one of us?" [laughs] There are clearly some psychologists who are not "one of us."

Carla: John, all this conversation about the participation of psychology on making models reminds me about that song we were singing some days ago, "Little boxes on the hillside"6...

John [sings along]: "They're all made of ticky tacky". [laughter]. There's lots of songs that I can only half remember. In the summer school, with Jim Wilson, and Peter Rober, and Justine Van Lawick, and Jaakko Seikkula, they all have to sing something. I know that Peter Rober sings a song that really grabs me, it's that... "turn, turn, turn"7. [Singing] "To everything (turn turn turn), there is a season (turn, turn turn) ... And a time...". But luckily, some of the people out there had the lyrics.[laughter] But it ends by... "A time of hate, a time of peace, a time for embracing... I swear it's not too late..." Nice song.

Carla: Very nice song. John, thank you very much for this moment as well, okay?

John: No problem. No difficulty. No problem. [laughs]

\section{REFERÊNCIAS}

Bernstein, B. (1971). Class, codes and control, vol. 1. London: Routledge and Kegan Paul.

6 "Little Boxes" is a song written by Malvina Reynolds. In 1963, it was recorded by Pete Seeger. The song is a political critique to the suburbia construction of houses ("houses made of ticky tacky") and to the middle-class attitudes and way of life at that period ("and they all look just the same"). In this dialogue with John Shotter, the song was used as a metaphor for thinking about the psychological production of labels and models, thus getting back to a prior theme.

7 "Turn, turn, turn - to everything there is a season", it's also a song by Pete Seeger, recorded in 1962. The lyrics are an adaptation of the Book of Eclesiastics, in the Bible. 
Billig, M. (1999). Freudian repression: conversation creating the unconscious. Cambridge: Cambridge University Press.

Billig, M. (2008). The language of critical discourse analysis: the case of nominalization. Discourse \& Society, 19(6), 783-800.

Gibson, J.J. (1979). The ecological approach to visual perception. London: Houghton Mifflin.

Gustavsen, B., Nyhan, B., \& Ennals, R. (Eds). (2007). Learning together for local innovation: promoting learning regions. Luxembourg: Office for Official Publications of the European Communities. (CEDEFOP reference series, 68). Recuperado em 24 de junho de 2013 de http://www.cedefop.europa.eu/EN/Files/3047_en.pdf

Halberstam, D. (1969). The best and the brightest. New York: Ballantine Books.

Macmurray, J. (1957). The self as agent. London: Faber and Faber.

Macmurray, J. (1961). Persons in relation. London: Faber and Faber.
Rawls, J. (1971). A theory of justice. Oxford: Oxford University Press.

Sen, A. (2009). The idea of justice. New York \& London: Harvard University Press \& Allen Lane.

Shotter, J. (1974). What is it to be human. In N. Armistead, Reconstructing Social Psychology. (pp.5371). Harmondsworth: Penguin Books.

Shotter, J. (1975). Images of man in psychological research. London: Methuen.

Shotter, J. (1984). Social accountability and selfhood. Oxford: Blackwell.

Uexküll, J. von (1957). A stroll through the world of animals and men. In C.H. Schiller (Ed.) Instinctive behaviour (pp.5-80). London: Methuen.

Recebido em 22/05/2013 Aceito em 01/07/2013

Carla Guanaes-Lorenzi: psicóloga, professora doutora do Departamento de Psicologia da Faculdade de Filosofia, Ciências e Letras de Ribeirão Preto (USP).

Pedro Pablo Sampaio Martins: psicólogo, doutorando no Programa de Pós-Graduação em Psicologia na Faculdade de Filosofia, Ciências e Letras de Ribeirão Preto (USP).

Clarissa Mendonça Corradi-Webster: psicóloga, professora doutora do Departamento de Psicologia da Faculdade de Filosofia, Ciências e Letras de Ribeirão Preto (USP).

Kátia de Souza Amorim: médica, professora associada do Departamento de Psicologia da Faculdade de Filosofia, Ciências e Letras de Ribeirão Preto (USP).

Emerson Fernando Rasera: psicólogo, professor associado da Universidade Federal de Uberlândia, bolsista produtividade CNPq - nível 2.

Murilo dos Santos Moscheta: psicólogo, professor adjunto dos cursos de graduação e pós-graduação em Psicologia da Universidade Estadual de Maringá. 


\section{ERRATA}

Psicologia em Estudo, Maringá, v. 18, n. 3, p. 561-569, jul./set. 2013

Guanaes-Lorenz, Carla, Martins, Pedro Pablo Sampaio, Corradi-Webster, Clarissa Mendonça, Amorim, Kátia de Souza, Rasera, Emerson Fernando, \& Moscheta, Murilo dos Santos. (2013). Envisioning a participatory democracy: an interview with John Shotter. Psicologia em Estudo, 18(3), 561-569. Retrieved August 04, 2014, from http://www.scielo.br/scielo.php?script=sci_arttext\&pid=S1413$73722013000300017 \&$ Ing=en\&tIng=en. 10.1590/S1413-73722013000300017.

- página 561, versão on line, na relação de autores, onde se lê: Guanaes-Lorenz, Carla, Martins, Pedro Pablo Sampaio, Corradi-Webster, Clarissa Mendonça, Amorim, Kátia de Souza, Rasera, Emerson Fernando, \& Moscheta, Murilo dos Santos.

leia-se: Guanaes-Lorenzi, Carla, Martins, Pedro Pablo Sampaio, Corradi-Webster, Clarissa Mendonça, Amorim, Kátia de Souza, Rasera, Emerson Fernando, \& Moscheta, Murilo dos Santos. O erro é no nome da primeira autora, sendo o correto Carla Guanaes-Lorenzi. Nas versões impressa e em PDF disponível on line não houve erro. 